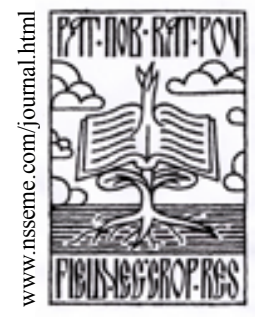

\title{
Occurrence of Heterodera schachtii in the Sugar Beet Growing Areas of Vojvodina, Serbia
}

\author{
Jasmina Bačić
}

received: 30 November 2012, accepted: 29 April 2013

published online: 28 May 2013

(c) 2013 IFVC

doi: $10.5937 /$ ratpov50-3003

\begin{abstract}
Summary: The survey on the occurrence of the sugar beet cyst nematode Heterodera schachtii Schmidt 1871 was performed from November 2006 until June 2012 in the sugar beet growing areas of the Serbian northern Province of Vojvodina. The soil samples were taken from 55 beet fields and analyzed for number of viable eggs or juveniles in the soil. In total, 1387 soil samples were collected from 20 sugar beet producers and 3 seed fodder beet producers. Fenwick can and electric device for crushing cysts were used in order to determine the presence of cysts and population density. Heterodera schachtii occurred in $36.36 \%$ of beet fields with population density ranging from 13 to 1591 eggs and second-stage juveniles in $100 \mathrm{~cm} 3$ of soil. The area with the most infected fields was the district of Bačka. Only in the district of Banat H. schachtii was not detected. Current occurrence of $\mathrm{H}$. schachtii in the sugar beet growing areas of Vojvodina indicates that this pest is most frequently found near old sugar beet factories in the districts of Bačka and Srem as a result of intensive sugar beet cultivation with narrow crop rotation.

Key words: Beta vulgaris, Heterodera schachtii, population density, Vojvodina
\end{abstract}

\section{Introduction}

The sugar beet nematode Heterodera schachtii Schmidt 1871 is a major parasite of sugar beet which is distributed worldwide (Ferreira \& Boley 1993). It causes significant yield loss especially in the conditions of intensive sugar beet production with narrow crop rotation. Yield reduction can be up to $50 \%$ when population densities are high (Ferreira \& Boley 1993).

Sugar beet (Beta vulgaris L.) is cultivated in the northern part of Serbia, in the autonomous Province of Vojvodina, covering about 61,000 ha (last three years average, Republic of Serbia 2012). The investigation of the occurrence of $H$. schachtii dates since the 1970 s. This pest was the most frequent in the sugar beet growing areas of Vojvodina (Krnjaić et al. 1981).

The basic strategy in fighting sugar beet cyst nematode is to keep the nematode population below the economic threshold. The most useful ways to achieve this is crop rotation (Greco 1983)

\section{J. Bačić}

Agricultural Extension Service Institute Tami

Novoseljanski put 33, 26000 Pančevo, Serbia

e-mail: jasmina.bacic@jasminabacic.rs and use of tolerant beet varieties (Wauters et al. 2010). The crop rotation period is usually more than once in 5 years and regular soil surveys for monitoring population densities (counts of viable cysts) are necessary (OEPP/EPPO 1994). Actual nematode tolerant varieties have been tested and are available in the recent years in Serbia (Bačić et al. 2007).

Many beet producers from this region have been reporting wilting and early death of beet in the last six years. This survey was performed as a result of long-term cooperation between Agricultural Extension Service Institute Tamiš and farmers reporting the yield reduction. In order to offer the farmers the proper recommendation on how to control sugar beet cyst nematode, it is necessary to have information about the number of viable eggs and juveniles in the soil before planting which was the aim of this study.

\section{Materials and Methods}

The survey of the occurrence of $H$. schachtii was carried out in the period between November 2006 and June 2012. In total, 1387 soil samples were collected from 20 sugar beet producers and 3 seed fodder beet producers. The samples were 


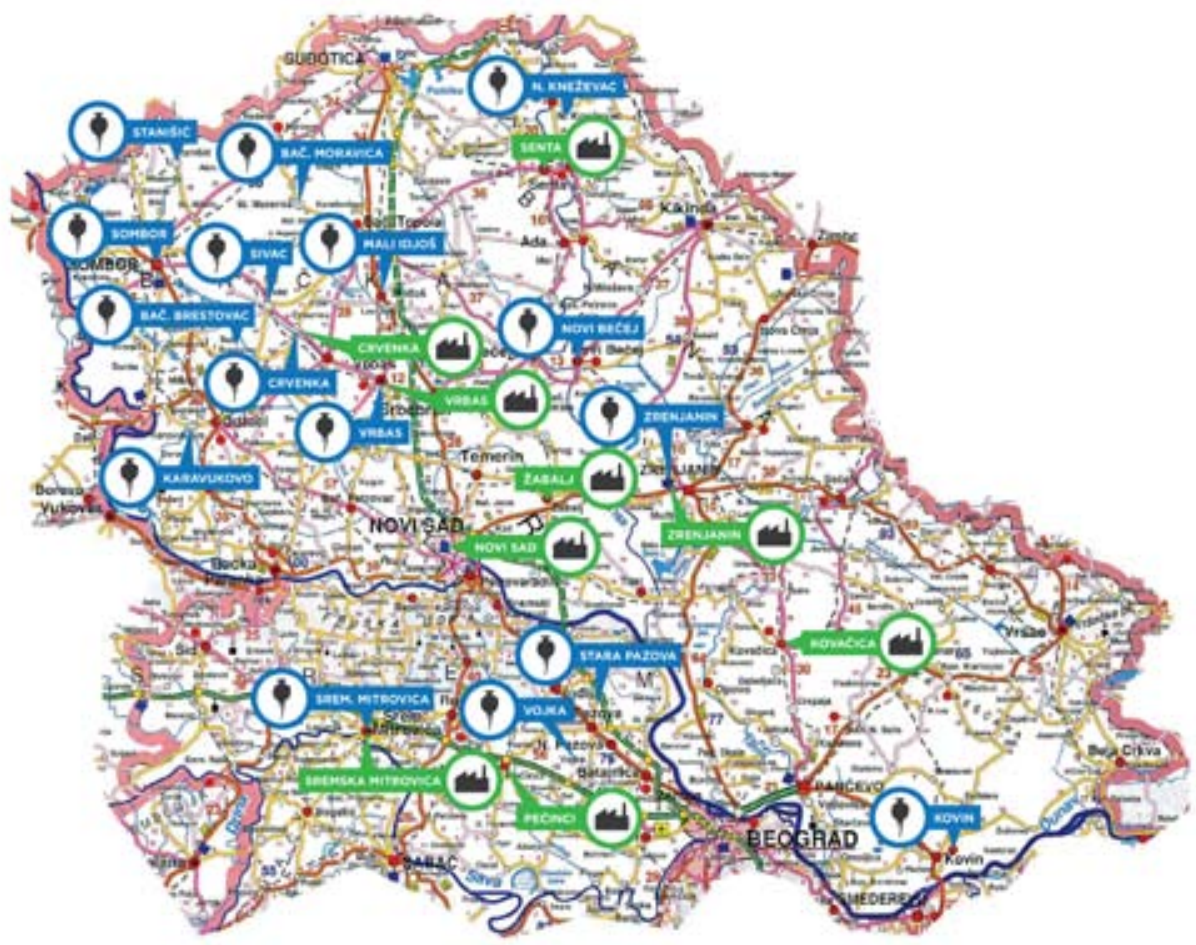

Legend: 9 Locations where soil samples were taken

Sugar beet factories

Figure 1. Map of Vojvodina province with locations where soil samples were taken and marked sugar beet factories

Slika 1. Mapa AP Vojvodine sa mestima gde su uzeti uzorci zemljišta i označenim fabrikama šećera

taken from 55 beet fields in Vojvodina during six years. It involved soil samples from 46 fields with symptoms of wilting and localized areas of poor growth during previous vegetations, 4 fields for testing tolerant beet varieties and 5 fields for planting seed fodder beet (Fig. 1). Producers were labelled with the letters (A, B, $C)$ and their fields with the numbers $(1,2,3)$, thus A-1 denotes the first field of producer A, etc.

One composite soil sample was collected per 1 ha. It consisted of 50 sub-samples from different points sampled on the depth of $10 \mathrm{~cm}$ with a special stick-auger $1 \mathrm{~cm}$ wide. Samples were processed in order to determine presence of cysts and population density of $H$. schachtii. Organic soil particles including cysts from soil samples were extracted on $250 \mu \mathrm{m}$ sieve using Fenwick can and transferred on filter paper for binocular inspection as described by Turner (1998). The species to which the cysts belonged were identified morphologically by the original description of vulval cone and second-stage juveniles (Franklin 1972).

For determination of cysts content, the method suggested by KWS SAAT AG Company was performed (Stephani 2006, personal communication). An electric device was used to crush cysts extracted from $100 \mathrm{~cm}^{3}$ of soil. An estimation of number of eggs and second-stage juveniles (J2) in homogenized solution was done using a microscope and counting chamber. Population density in $100 \mathrm{~cm}^{3}$ of soil was calculated by multiplying the number of viable eggs and $\mathrm{J} 2$ in $1 \mathrm{ml}$ of solution with the number of $\mathrm{ml}$ in the cylinder. Data on population density on beet fields (average number of cysts and average number of eggs and $\mathrm{J} 2$ in $100 \mathrm{~cm}^{3}$ of soil) are presented as mean $(\mathrm{M}) \pm$ standard deviation (SD). 


\section{Results and Discussion}

The current occurrence of $H$. schachtii in Vojvodina is shown in Table 1 (districts of Banat and Srem) and Table 2 (district of Bačka). In total, vital cysts occurred in $36.36 \%$ of beet fields. Cysts without vital content were in $5.45 \%$ of fields. The sugar beet nematode was not detected in soil from seed fodder beet fields and 28 sugar beet fields. The area with the most infested soil $(80 \%$ of fields) was in the district of Bačka-localities of Crvenka, Kula, Vrbas, Sivac and Novi Bečej. In the western part, in the district of Srem, $20 \%$ of infested fields were found (localities of Vojka and Stara Pazova). Only in the district of Banat $H$. schachtii was not detected.

The average number of eggs and $\mathrm{J} 2$ in $100 \mathrm{~cm}^{3}$ of soil ranged from 13 to 1591 . The lowest (Q-1) and the highest abundance (I-6) were observed in the same area in the northern part of Vojvodina. Low incidence of the parasite below 150 eggs and $\mathrm{J} 2$ was found in $30 \%$ of fields. The population density at mid-level from 150 to 300 eggs and $\mathrm{J} 2$ was detected in $20 \%$ of fields. Relatively high incidence with density from 300-800 eggs and J2 was observed in $10 \%$ of fields. The highest density above 800 eggs and $\mathrm{J} 2$ was found in $40 \%$ of beet fields.

Today, distribution of the sugar beet nematode in Serbia, compared to data from the 1970s is different because sugar beet has been planted only in the province of Vojvodina for the last decade. Current occurrence of vital cysts in 20 of 55 beet fields (36.36\%) in Vojvodina indicates the use of narrow, mostly 2-year crop rotation (wheat or corn/beet) as a consequence of the lack of available fields. Cysts without vital content found in 5.45\% of fields confirm the use of proper crop rotation. The sugar beet nematode was not detected in soil from seed fodder beet fields. The number of these fields is much smaller than the number of sugar beet fields in Vojvodina.

A survey conducted in 2005 (238 fields) and 2006 (237 fields) revealed that $42 \%$ of the sugar beet area in the Netherlands was infested with Heterodera schachtii. Beet cyst nematode was most abundant in the South West of the Netherlands, a region with a long history of sugar beet cultivation (Schneinder \& Wevers 2007). In Netherlands, eleven percent of the area was infested with at least 300 eggs and larvae per $100 \mathrm{ml}$ soil (Schneinder \& Raaijmakers 2008). In the sugar beet production area of Vojvodina, the region with the most infected fields was the district of Bačka. In this district, sugar beet is the most intensively cultivated crop. This area is one of the oldest sugar beet growing areas with the most numerous sugar beet factories.

In the Austrian sugar beet production area, 29 out of the 48 selected plots in 2008 and 19 out of

Table 1. Occurrence of Heterodera schachtii in the sugar beet growing areas of the districts of Banat and Srem

Tabela 1. Prisustvo Heterodera schachtii u regionima gajenja šećerne repe Banata i Srema

\begin{tabular}{cccc}
\hline Locality & Producer- & $\begin{array}{c}\text { Average number of } \\
\text { cysts } / 100 \mathrm{~cm}^{3} \text { of soil } \\
\mathrm{M} \pm \mathrm{SD}\end{array}$ & $\begin{array}{c}\text { Average number eggs and J2/100 } \\
\mathrm{cm}^{3} \text { of soil } \\
\mathrm{M} \pm \mathrm{SD}\end{array}$ \\
\hline Sugar beet field & A-1 & 0.00 & 0.00 \\
Zrenjanin & $\mathrm{A}-2$ & 0.00 & 0.00 \\
Zrenjanin & $\mathrm{A}-3$ & 0.00 & 0.00 \\
Zrenjanin & $\mathrm{B}-1$ & 0.00 & 0.00 \\
Zrenjanin & $\mathrm{C}-1$ & 0.00 & 0.00 \\
Kovin & & & \\
& & & $1126.66 \pm 607.70$ \\
District of Srem & $\mathrm{D}-1$ & $29.66 \pm 16.81$ & $1070.00 \pm 98.88$ \\
Vojka & $\mathrm{D}-2$ & $37.00 \pm 1.41$ & $1280.00 \pm 28.28$ \\
Vojka & $\mathrm{D}-3$ & $36.50 \pm 6.50$ & 0.00 \\
Vojka & $\mathrm{E}-1$ & $11.75 \pm 1.89$ & 0.00 \\
Stara Pazova & F-1 & 0.00 & $0.00 \pm 107.08$ \\
Stara Pazova & G-1 & 0.00 & \\
Sremska Mitrovica & & &
\end{tabular}

Key: * seed fodder beet 
Table 2. Occurrence of $H$. schachtii in the sugar beet growing areas of the district of Bačka

Tabela 2. Prisustvo Heterodera schachtii u regionima gajenja šećerne repe Bačke

\begin{tabular}{|c|c|c|c|}
\hline $\begin{array}{l}\text { District of Bačka } \\
\text { Locality }\end{array}$ & $\begin{array}{c}\text { Producer- } \\
\text { Sugar beet field }\end{array}$ & $\begin{array}{c}\text { Average number of } \\
\text { cysts/100 } \mathrm{cm}^{3} \text { of soil } \\
\mathrm{M} \pm \mathrm{SD}\end{array}$ & $\begin{array}{l}\text { Average number eggs and } \mathrm{J} 2 / 100 \\
\mathrm{~cm}^{3} \text { of soil } \\
\mathrm{M} \pm \mathrm{SD}\end{array}$ \\
\hline Crvenka & $\mathrm{H}-1$ & 0.00 & 0.00 \\
\hline Crvenka & $\mathrm{I}-1$ & $5.85 \pm 6.22$ & $138.57 \pm 176.57$ \\
\hline Crvenka & $\mathrm{I}-2$ & $13.11 \pm 7.59$ & $154.71 \pm 176.57$ \\
\hline Crvenka & $\mathrm{I}-3$ & 0.00 & 0.00 \\
\hline Crvenka & $\mathrm{I}-4$ & 0.00 & 0.00 \\
\hline Crvenka & I-5 & 0.00 & 0.00 \\
\hline Crvenka & I-6 & $12.25 \pm 5.41$ & $1591.66 \pm 588.52$ \\
\hline Crvenka & I-7 & $18.77 \pm 12.00$ & $976.66 \pm 734.59$ \\
\hline Crvenka & I- 8 & 0.00 & 0.00 \\
\hline Crvenka & I-9 & 0.00 & 0.00 \\
\hline Crvenka & $\mathrm{I}-10$ & 0.00 & 0.00 \\
\hline Crvenka & $\mathrm{I}-11$ & 0.00 & 0.00 \\
\hline Crvenka & $\mathrm{I}-12$ & $0.52 \pm 1.18$ & 0.00 \\
\hline Crvenka & $\mathrm{I}-13$ & 0.00 & 0.00 \\
\hline Crvenka & I-14 & $0.66 \pm 1.07$ & 0.00 \\
\hline Crvenka & $\mathrm{I}-15$ & 0.00 & 0.00 \\
\hline Crvenka & $\mathrm{I}-16^{* *}$ & $14.00 \pm 5.65$ & $250.00 \pm 70.71$ \\
\hline Crvenka & $\mathrm{I}-17$ & $5.60 \pm 4.47$ & $119.40 \pm 159.22$ \\
\hline Crvenka & $\mathrm{I}-18$ & 0.00 & 0.00 \\
\hline Kula & $\mathrm{J}-1$ & $17.66 \pm 9.91$ & $946.66 \pm 447.90$ \\
\hline Sivac & $\mathrm{K}-1$ & $1.05 \pm 1.89$ & 0.00 \\
\hline Sivac & $\mathrm{K}-2$ & 0.00 & 0.00 \\
\hline Sivac & $\mathrm{K}-3$ & 0.00 & 0.00 \\
\hline Sivac & $\mathrm{K}-4$ & 0.00 & 0.00 \\
\hline Sivac & L-1 & $22.75 \pm 7.93$ & $630.00 \pm 373.98$ \\
\hline Vrbas & M-1 & $9.50 \pm 5.04$ & $247.50 \pm 142.60$ \\
\hline Vrbas & $\mathrm{M}-2$ & $8.55 \pm 6.93$ & $128.00 \pm 139.98$ \\
\hline Vrbas & $\mathrm{N}-1$ & $7.66 \pm 2.62$ & $17.00 \pm 11.04$ \\
\hline Vrbas & $\mathrm{O}-1^{* *}$ & $14.50 \pm 6.32$ & $225.00 \pm 186.48$ \\
\hline Vrbas & $\mathrm{O}-2^{* *}$ & $22.33 \pm 6.18$ & $1540.00 \pm 381.92$ \\
\hline Novi Bečej & $\mathrm{O}-3^{* *}$ & $69.00 \pm 25.45$ & $1380.00 \pm 509.11$ \\
\hline Bački Brestovac & P-1 & 0.00 & 0.00 \\
\hline Bačka Moravica & Q-1 & $7.66 \pm 2.62$ & $13.00 \pm 11.04$ \\
\hline Bačka Moravica & $\mathrm{Q}-2$ & 0.00 & 0.00 \\
\hline Bačka Moravica & Q-3 & $1.91 \pm 2.78$ & $26.25 \pm 65.21$ \\
\hline Mali Iđoš & $\mathrm{R}-1$ & 0.00 & 0.00 \\
\hline Kneževac & $S-1$ & 0.00 & 0.00 \\
\hline Kneževac & $S-2$ & 0.00 & 0.00 \\
\hline Stanišić & $\mathrm{T}-1$ & 0.00 & 0.00 \\
\hline Sombor & $\mathrm{U}-1$ & 0.00 & 0.00 \\
\hline Sombor & $V-1^{*}$ & 0.00 & 0.00 \\
\hline Karavukovo & $\mathrm{W}-1^{*}$ & 0.00 & 0.00 \\
\hline Karavukovo & W-2* & 0.00 & 0.00 \\
\hline Karavukovo & W-3* & 0.00 & 0.00 \\
\hline
\end{tabular}

Key: ${ }^{*}$ seed fodder beet, ${ }^{* *}$ beet varieties trial 
35 in 2009 were found not to be infested with $H$. schachtii. In total, 16 of these showed only slight infestation (up to $500 \mathrm{~J} 2 / 100 \mathrm{~g}$ of soil) in 2008 as well as 14 in 2009 (Sigl et al. 2010). In the sugar beet production area of Vojvodina, 11 selected plots were slightly infected.

The international economic thresholds for this pest are different. The average threshold in western Nebraska was 2.8 eggs or juveniles $/ \mathrm{cm}^{3}$ of soil. Initial soil population density of approximately 3 eggs, range between 2 and 4 juveniles in $1 \mathrm{~cm}^{3}$ of soil may result in yield loss (Gray et al. 1992).

The weather conditions in Vojvodina during 2007 and 2012 with rainy spring and dry summer were very favourable for nematodes. The followup on this study will be determination of the thresholds in sugar beet growing areas in Vojvodina in order to give proper recommendation of crop rotation to farmers.

\section{Conclusions}

The findings from previous six years indicate that $H$. schachtii is most frequently found near old sugar beet factories in Vojvodina. This became a problem in the sugar beet growing areas of the districts of Bačka and Srem as a result of intensive sugar beet cultivation with narrow crop rotation. In order to get more stable yields on farms, it is necessary to monitor $H$. schachtii in sugar beet fields before planting. This research is a basis for further investigations of real damaging levels and influence of tolerant beet varieties on nematode population in these areas.

\section{References}

Bačić, J., Gujaničić, T., Martić, M., \& Međeši, B. (2007). Prisustvo repine nematode na području Crvenke u 2006/07. godini. Zbornik rezimea XIII Simpozijuma sa savetovanjem o zaštiti bilja, Zlatibor, Srbija. 84.

Ferreira, S.A., \& Boley, R.A. (1993). Heterodera schachtii. Department of Plant Pathology, University of Hawaii at Manoa. Retrieved 2012 June 5 from http://www.extento.hawaii.edu/kbase/crop/ type/h_schac.htm

Franklin, M.T. (1972). Heterodera schachtii. C.I.H. Descriptions of Plant-parasitic Nematodes. Set 1. In: Heterodera schachtii-Morphology and Anatomy. Nemaplex page (p. 4). Commonwealth Institute of Parasitology. C.A.B. International. Retrieved 2012 June 5 from http://plpnemweb.ucdavis.edu/nemaplex/ taxadata/G060S7.HTM

Gray, F.A., Franc, G.D., \& Kerr, E.D. (1992). Sugar beet nematode. University of Wyoming. Retrieved 2012 June 5 from http://nematode.unl.edu/extpubs/ wyosbn.htm.

Greco, N. (1983). The sugar beet cyst nematode in Italy: Distribution, yield losses and control. Nematol. Mediterr., 13, 1-5.

Krnjaić, Đ., Krnjaić, S., \& Kondić, Đ. (1981). Osvrt na rasprostranjenost i prognozu repine nematode (Heterodera schachtii Schm). Zaštita bilja, 32, 158(4), 443-450.

OEPP/EPPO (1994). EPPO Standard PP 2/1(1) Guideline on good plant protection practice: principles of good plant protection practice. EPPO Bulletin, 24(2), 233-240.

Republic of Serbia. (2012). Agriculture and fishery, crop farming. Statistical Office of the Republic of Serbia, Belgrade. Retrieved 2012 June 5 from http://webrzs.stat.gov.rs

Schneiner, J.H.M., \& Wevers, J.D.A. (2007). Abundance and an improved management strategy of beet cyst nematodes in the Netherlands. Abstracts and proceedings 70 th IIRB (International Institute for beet research) Congress. Marrakech, Morocco. Retrieved 2013 April 2 from http://www.iirb.org/media/70_schneider_et_al_abstracts.pdf

Schneiner, J.H.M., \& Raaijmakers, E.E.M. (2008). Management of beet cyst nematodes in the Netherlands. Abstracts and proceedings 71st IIRB (International Institute for beet research) Congress. Brussels, Belgium. Retrieved 2012 April 2 from http:/ /www.iirb.org/ media/71_schneider_raajmakers_abstracts.pdf

Sigl, G., Eigner, H., Kempl, F., \& Grundler, F. (2010). 
Occurrence of Heterodera schachtii in the Austrian sugar beet production area. Abstracts and proceedings 72nd IIRB (International Institute for beet research) Congress. Copenhagen, Denmark. Retrieved 2012 June 5 from http://www.iirb.org/media/sigl i abstract $72 \mathrm{nd}$ congress.pdf

Turner, S.J. (1998). Sample preparation, soil extraction and laboratory facilities for the detection of potato cyst nematodes. In: R.J. Marks \& B.B. Brodie (Eds.), Potato Cyst Nematodes-Biology, Distribution and
Control (pp. 75-91). Wallingford: CAB International.

Wauters, A., Champeil, A., Muchembled, C., \& Daub, M. (2010). Perfomance of nematode tolerant sugar beets in Europe-on field situation and nematode magement strategies. Abstracts and proceedings $72 n d$ IIRB (International Institute for beet research) Congress, Copenhagen, Denmark. Retrieved 2012 August 2 from http://www.iirb.org/media/wauters_ abstract_72nd_congress-1.pdf.

\title{
Prisustvo Heterodera schachtii u regionima gajenja šećerne repe Vojvodine
}

\author{
Jasmina Bačić
}

Sažetak: Istraživanje prisustva repine nematode Heterodera schachtii Schmidt 1871 u regionima gajenja šećerne repe Vojvodine sprovedeno je u periodu od novembra 2006. do juna meseca 2012. godine. Uzorci zemljišta su uzeti i analizirani poreklom sa 55 parcela. Ukupno je sakupljeno 1387 uzoraka zemljišta kod 20 proizvođača šećerne repe i 3 proizvođača semenske stočne repe. U cilju određivanja prisustva cista i gustine populacije korišćeni su Fenwick flotacioni aparat i električna mehanička mešalica za gnječenje cista. Heterodera schachtii je utvrđena na 36,36\% parcela sa gustinom populacije u rasponu od 13 do 1591 jaja i jedinki drugog juvenilnog stadijuma u $100 \mathrm{~cm} 3$ zemljišta. Najveći broj zaraženih parcela konstatovan je u regionu Bačke. Samo u regionu Banata H. schachtii nije konstatovana. Sadašnja saznanja o prisustvu H. schachtii u regionima gajenja šećerne repe Vojvodine ukazuju da je pojava ove štetočine najučestalija blizu starih fabrika šećera u regionima Bačke i Srema kao posledica intenzivnog gajenja šećerne repe i primene uskog plodoreda.

Ključne reči: Beta vulgaris, gustina populacije, Heterodera schachtii, Vojvodina 